\title{
Cytotoxicity and antitumoral activity of dichloromethane extract and its fractions from Pothomorphe umbellata
}

\author{
J.L. Sacoman 1,2 , K.M. Monteiro², A. Possenti², G.M. Figueira², M.A. Foglio² and \\ J.E. Carvalho ${ }^{1,2}$
}

${ }^{1}$ Departamento de Biologia Celular e Estrutural, Instituto de Biologia, ${ }^{2}$ Centro Pluridisciplinar de

Pesquisas Químicas, Biológicas e Agrícolas, Universidade Estadual de Campinas, Campinas, SP, Brasil

Correspondence to: J.L. Sacoman, Departamento de Biologia Celular e Estrutural, Instituto de Biologia, UNICAMP, Caixa Postal 6171, 13083-970 Campinas, SP, Brasil

Fax: +55-19-3884-7811. E-mail: juliana@cpqba.unicamp.br

\begin{abstract}
The cytotoxicity of the dichloromethane crude extract (DCE), obtained from the aerial parts of Pothomorphe umbellata (L.) Miq (Piperaceae), was evaluated against nine human cancer cell lines (MCF-7, NCl-ADR/RES, OVCAR-3, PC-3, HT-29, NCI-H460, 786-O, UACC-62, K-562). The DCE presented antiproliferative activity with good potency against all cell lines at low concentrations (between 4.0 and $9.5 \mu \mathrm{g} / \mathrm{mL})$ and with selectivity $(1.55 \mu \mathrm{g} / \mathrm{mL})$ for the leukemia cell line (K-652). DCE (100, 200, 300 and $400 \mathrm{mg} / \mathrm{kg}$, ip) was also evaluated in the Ehrlich ascites tumor model. Both the survival number and the life span of the animals that died increased by at least 45 and $50 \%$, respectively ( 8 animals per group), demonstrating $P$. umbellata extract potential anticancer activity. The results of the in vivo antitumor activity prompted the fractionation of the crude extract. The crude extract was submitted to dry column chromatography with dichloromethane-methanol (99:1). The column effluent fractions were extracted with methanol, dried under vacuum yielding fractions FR1 (less polar), FR2 (medium polarity), and FR3 (polar), which were analyzed for their growth inhibition or cytotoxic properties by a 48-h sulforhodamine B cell viability assay by measuring the total protein content. FR1 demonstrated high potency and cytotoxicity, a result compatible with the high toxicity of oxalic acid; FR2, containing 4-nerolidylcathecol, presented the lowest cytotoxic activity compared to the other two fractions but with selectivity for prostate cancer cell line; FR3, containing a mixture of steroids described in the literature as possessing various biological activities, also presented potent anticancer in vitro activity. These results suggest that $P$. umbellata DCE in vivo antitumor activity may be a consequence of the activity of different active principles.
\end{abstract}

Key words: Pothomorphe umbellata; Piperaceae; Antitumor activity; Ehrlich ascites tumor

Research supported by FAPESP and CNPq.

Received June 20, 2007. Accepted April 30, 2008

For many centuries, plants have provided a rich source of therapeutic agents and bases for synthetic drugs. Despite the great development of organic synthesis, currently $25 \%$ of prescribed drugs worldwide are still derived from plant sources, showing that plant species are still an important source of new drugs for diseases that continue to lack a cure, such as cancer (1).

Pothomorphe umbellata, also known as "pariparoba", is a Brazilian shrub with large round leaves and inflores- cence with small conical white and hermaphrodite flowers (2). In folk medicine, this plant is used for the treatment of a variety of diseases described in the first edition of the Brazilian Pharmacopoeia (3). A great amount of pharmacological studies have been undertaken with this species and, as a result, many extracts obtained from this plant have demonstrated interesting biological actions such as photo-protection (4), anti-inflammatory, analgesic (5), and anti-ophidian properties (6). Many of these studies focus 
on the biological activity of 4-nerolidylcathecol, already described by Kijjoa et al. (7). Few data mention, however, the potential anticancer activity of this species $(8,9)$. Thus, we investigated the antitumor activity of dichloromethane crude extract (DCE) and fractions obtained from $P$. umbellata.

In order to investigate the antitumor activity, fresh aerial parts of $P$. umbellata were collected at the Centro Pluridisciplinar de Pesquisas Químicas, Biológicas e Agrícolas experimental field (Campinas, SP, Brazil). The plant was identified by Dr. Maria do Carmo E. Amaral (Instituto de Biologia, UNICAMP, Campinas, SP, Brazil) and placed in the Universidade Estadual de Campinas' Herbarium collection, under\#127.123. Fresh ground leaves $(100 \mathrm{~g})$ were extracted by maceration with $1000 \mathrm{~mL}$ dichloromethane P.A. (Merck, Germany). The solvent was evaporated under reduced pressure at $30^{\circ} \mathrm{C}$, providing $2.5 \mathrm{~g}$, a $2.5 \%$ yield of DCE. The crude extract was submitted to dry column chromatography with dichloromethane-methanol (99:1). The column fractions were extracted with methanol, dried under vacuum, and the resulting FR1 (less polar), FR2 (medium polarity) and FR3 (polar) fractions were submitted to in vitro cytotoxicity analysis. The separation of the compound was monitored by thin layer chromatography (dichloromethane-methanol, 98:2) performed on precoated plates (775554, Merck). The three fractions were also analyzed using a gas chromatography/mass spectrometry system (GC/MS, Hewlett-Packard, 6890/ 5975, USA) equipped with a J\&W Scientific DB-5 fused silica capillary column $(25 \mathrm{~m} \times 0.2 \mathrm{~mm} \times 0.33 \mu \mathrm{m})$. The temperature of the program used was: $110^{\circ} \mathrm{C}(2 \mathrm{~min}) ; 5^{\circ} \mathrm{C} /$ min until $300^{\circ} \mathrm{C}$; injector and detector temperature: $250^{\circ} \mathrm{C}$. Helium was employed as the carrier gas. The MS were taken at $70 \mathrm{eV}$. Scanning speed was 0.84 scans/s from 40 to 550 .

Since different cell lines display various sensitivities towards cytotoxic compounds, the use of more than one cell line was therefore considered necessary for the detection of these substances. The activity-guided fractionation of dichloromethane soluble extract was monitored by in vitro cytotoxic activity assay in UACC-62 (melanoma), MCF-7 (breast), NCl-H460 (lung, non-small cells), OVCAR3 (ovarian), PC-3 (prostate), HT-29 (colon), 786-O (renal), $\mathrm{NCl}-\mathrm{ADR} / \mathrm{RES}$ (ovarian expressing phenotype multiple drugs resistance) and K-562 (leukemia) cancer cell lines. A 48-h sulforhodamine B cell viability assay was performed to determine growth inhibition and cytotoxic properties of DCE and fractions (10). Extracts and fractions were tested on the 9 cell lines over a 3-log concentration range $(0,0.25,2.5,25$, and $250 \mu \mathrm{g} / \mathrm{mL})$. The absorbance data $(540 \mathrm{~nm})$ was the starting point for the construction of a dose-response curve. According to Holbeck (11), three endpoints can be calculated for each cell line. The $\mathrm{GI}_{50}$ is the concentration required to inhibit $50 \%$ of the cell line growth compared to the untreated ones (which corresponds to $0 \mu \mathrm{g} / \mathrm{mL}$ point). The TGI is the concentration that causes total growth inhibition and the $\mathrm{LC}_{50}$ is the concentration needed to kill $50 \%$ of the cells (11). In the present research, we used the TGI endpoint to compare the potency and specificity of the extracts and the fractions. Doxorubicin was used as a positive control because of its large range of activity against many solid tumors and leukemias.

For the in vivo studies, adult male Swiss mice were obtained from CEMIB (UNICAMP) and maintained under controlled conditions of temperature $\left(22-24^{\circ} \mathrm{C}\right)$, light $(12-\mathrm{h}$ light/12-h dark), and humidity (45-65\%), with food and water ad libitum. All animals used for the experimental research had a body weight of $30-40 \mathrm{~g}$. All procedures were in accordance with the Bioethics Committee of the Instituto de Biologia (CEEA, UNICAMP, protocol 887-1 guidelines).

Three groups of 5 animals each were treated with 100 , 300 and $1000 \mathrm{mg} / \mathrm{kg}$ DCE (ip). The number of deaths was determined during the following 15 days and afterwards all animals were sacrificed. The $\mathrm{LD}_{50}$, showing which concentrations produced potential therapeutic activity but did not kill the animals (12), was calculated by linear regression.

Ehrlich tumor cells were maintained in male Swiss mice using serial ip inoculation at 7-day intervals in ascitis form. After preparing the cells, the total number was determined by the trypan blue dye exclusion method, with tumor cell viability always higher than $90 \%$. The cells were then diluted in $0.9 \%$ saline for final inoculation density $\left(1 \times 10^{5}\right.$ cells $/ \mathrm{mL})$.

$P$. umbellata DCE antitumor activity was evaluated in two long-term (90 days) Ehrlich-ascites tumor (EAT) assays (13). Three groups of 8 animals each in the first term and five groups of 8 animals in the second term received $10^{5} \mathrm{cells} / \mathrm{mL}$, ip. Drug administration (ip) began on the 4th day after inoculation, and the groups received the following treatments: saline (vehicle) as negative control; $5 \mathrm{mg} /$ $\mathrm{kg}$ doxorubicin (Tecnofarma International, St. Louis, MO, USA) as positive control; $300 \mathrm{mg} / \mathrm{kg}$ DCE in the pilot experiment and in 3 doses in the second experiment (100, 200 and $400 \mathrm{mg} / \mathrm{kg}$ ). The animals were treated again at the same doses on the 14th and 21st days after inoculation and were observed and scored daily for behavior and clinical conditions according to Ullman-Cullere and Foltz (14). When an animal received a score of 16 or more, according to these criteria, the animal was sacrificed and that day was considered to be the day of its death. Kaplan- 
Meier survival curves were analyzed by the log-rank test.

The DCE in vitro cytotoxicity evaluation demonstrated a high potency showing a good concentration and effect relationship, with more selectivity for leukemia cell line $(\mathrm{K}$ 562), with a TGI of $1.55 \mu \mathrm{g} / \mathrm{mL}$. The positive control, doxorubicin, showed high cytotoxic activity in most cell lines with the exception for $\mathrm{NCl}-\mathrm{ADR} / \mathrm{RES}$, which expressed a multidrug resistance phenotype, a fact in accordance with the TGI of $136.96 \mu \mathrm{g} / \mathrm{mL}$ (Table 1). This high in vitro cytotoxicity prompted the study of DCE activity in a murine cancer model.

Before the study in a murine cancer model, a short acute toxicity evaluation was conducted in order to determine the $L D_{50}$ and the doses to be used in long-term studies. After treatment, the behavior and death during 15 days of DCE-treated mice were observed. With 100 and $200 \mathrm{mg} / \mathrm{kg}$, animals demonstrated an increase in exploratory and locomotory activities. However, a higher dose $(1000 \mathrm{mg} / \mathrm{kg}$ ) produced death. The number of deaths by group generated a $\mathrm{LD}_{50}$ value of $533.71 \mathrm{mg} / \mathrm{kg}$. Therefore, this dose was used as a parameter for planning the treatment of animals with EAT. The in vivo antitumor activity was determined by the survival time and number of deaths of the treated groups compared to the control (Figure 1). In Figure $1 \mathrm{~A}$, the $300 \mathrm{mg} / \mathrm{kg}$ dose increased survival by $50 \%$ compared to the negative control group. It also increased the life span in almost $50 \%$, with the first death occurring only 50 days after the beginning of the experiment. There was $100 \%$ survival in the doxorubicin group, demonstrating antitumoral activity (Figure 1A and B). The $400 \mathrm{mg} / \mathrm{kg}$
DCE dose presented high toxicity causing the whole group to die before the negative control group (Figure 1B). Furthermore, 100 and $200 \mathrm{mg} / \mathrm{kg}$ DCE doses increased the survival rate by $50 \%$ or more.

The antitumor activity observed for this animal model prompted the identification of the main compounds of the fractions involved in anticancer activity. The active fractions were analyzed by GC/MS. Comparison of experimental data with the literature $(15,16)$ and Nist database available in the GC/MS demonstrated the following: the FR1 fraction is a mixture of oxalic acid derivatives, FR2

Table 1. Concentration of Pothomorphe umbellata fractions required for total growth inhibition of tumor cell lines.

\begin{tabular}{lccccc}
\hline \multirow{2}{*}{ Cell line } & \multicolumn{5}{c}{ Total growth inhibition } \\
\cline { 2 - 6 } & DCE & FR1 & FR2 & FR3 & DOX \\
\hline UACC-62 & 5.73 & 2.79 & 39.7 & 0.11 & 0.27 \\
MCF-7 & 8.96 & 0.29 & 12.3 & 0.08 & 68.5 \\
NCI-H460 & 4.28 & 0.12 & 191.3 & 0.24 & 4.68 \\
K-562 & 1.55 & 0.04 & 8.57 & 0.05 & 1.39 \\
OVCAR-3 & 6.08 & 0.90 & 11.8 & 0.03 & 38.1 \\
PC-3 & 5.34 & 7.36 & 4.84 & 2.68 & 12.6 \\
HT-29 & 9.38 & 5.89 & 32.8 & 0.38 & 112 \\
786-O & 6.55 & 10.3 & 14.6 & 1.73 & 7.69 \\
NCI-ADR/RES & 9.32 & 0.03 & 17.3 & 0.15 & 137 \\
\hline
\end{tabular}

Data are reported as $\mu \mathrm{g} / \mathrm{mL}$ for 3 replicates per treatment in two independent tests at $25^{\circ} \mathrm{C}$ for $48 \mathrm{~h}$. DCE = dichloromethane crude extract; FR1, FR2 and FR3 = crude extract fractions; DOX $=$ doxorubicin (positive control).
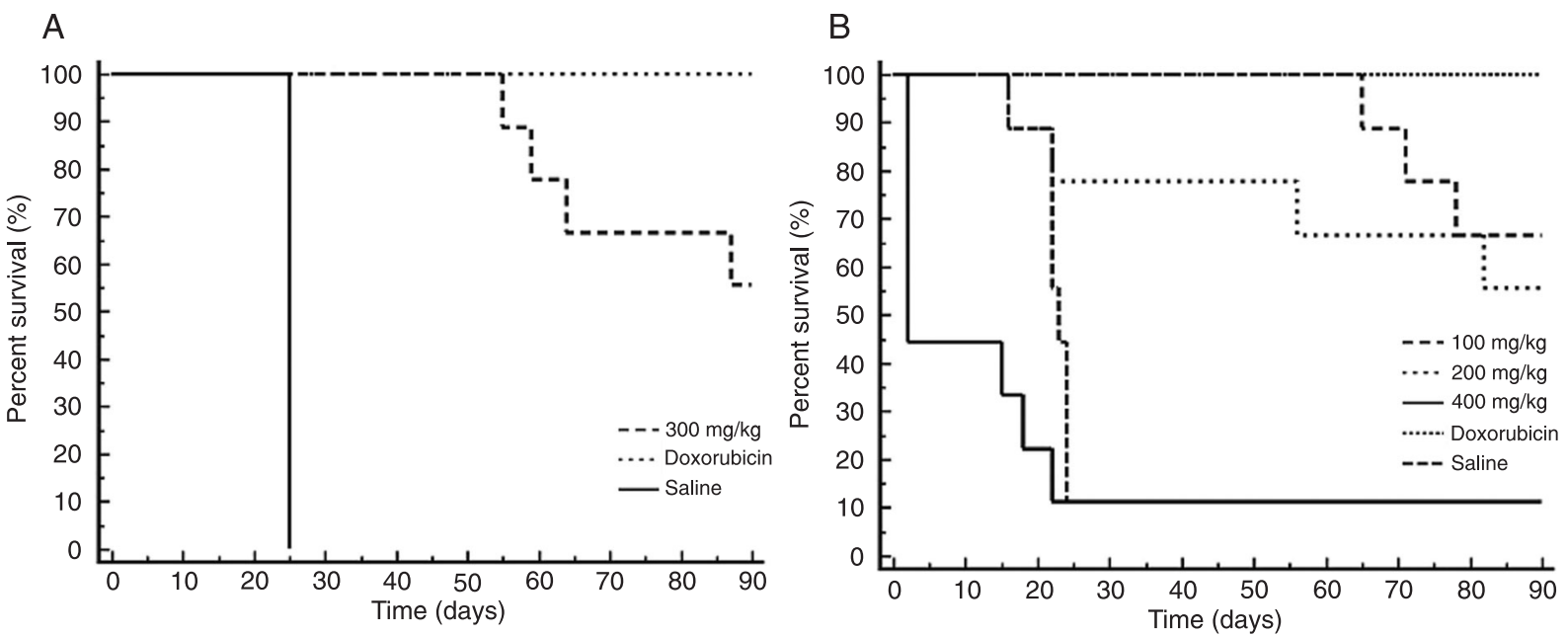

Figure 1. Kaplan-Meier survival curves of mice (8 animals per group) treated with Pothomorphe umbellata dichloromethane crude extract. Doses $(A) 300 \mathrm{mg} / \mathrm{kg}(P=0.0002)$ and $(B) 100(P<0.0001), 200(P<0.0001)$, and $400 \mathrm{mg} / \mathrm{kg}(P<0.0001)$. Controls: saline (negative) and doxorubicin (positive, $5 \mathrm{mg} / \mathrm{kg}$ ). Day 0 is the day of cell inoculation and days 4,11 (A) and 4, 11 and 18 (B) are the days of treatment. The survival curves were analyzed by the rank-log test, which indicates the statistical difference between the number of deaths in the negative control group (saline) and the treated ones. 
contains 4-nerolidylcathecol as the major component, and the FR3 fraction is a mixture of ß-sitosterol, stigmasterol and campesterol with $\mathrm{m} / \mathrm{z} 414,412$ and 400, respectively.

The fact of fraction FR1 being rich in oxalic acid derivatives can be correlated with the high toxicity observed in DCE high doses. If the TGI values of DCE and FR1 are compared (Table 1), it is remarkable that the specific activity increased just two times for UACC-62 but 310 times for $\mathrm{NCl}-\mathrm{ADR} / \mathrm{RES}$, while the other $5 \mathrm{TGl}$ are in this range. The highest potency of FR1 was against NCI-ADR/ RES, followed by $\mathrm{K}-562, \mathrm{NCl}-\mathrm{H} 460$ and MCF-7 TGI values. This activity against different cell lines might arise from different mechanisms of action used by the different chemical components of FR1 in order to kill tumor cell lines.

Fraction FR2 has 4-nerolidylcathecol as the main component and has the lowest cytotoxicity among the three fractions evaluated. When compared to DCE TGI values, it is noticeable that FR2 loses its potency for all cell lines, except for PC-3. This high selectivity for a prostate cancer cell should be considered for further studies. The minor cytotoxic activity cannot be definitely attributed to 4nerolidylcathecol because this compound was not totally purified. However, other data attribute considerable cytotoxic action to this molecule $(8,9)$. The topoisomerase I inhibition attributed to 4-nerolidylcathecol (8) could also corroborate the in vivo antitumor activity observed.

The polar fraction FR3 also had high potency, with a TGI value below $0.5 \mu \mathrm{g} / \mathrm{mL}$ for most cell lines and increased the specific activity for all cell lines (Table 1). This fraction consists of a mixture of ß-sitosterol, stigmasterol and campesterol steroids that had a high cytotoxicity for OVCAR-3 and K-562 cell lines, followed by MCF-7, UACC62 and $\mathrm{NCl}-\mathrm{ADR} / \mathrm{RES}$. These steroids, mainly ß-sitosterol, have demonstrated anti-inflammatory and cytotoxic activi-

\section{References}

1. Rates SM. Plants as source of drugs. Toxicon 2001; 39: 603-613.

2. Moraes MS. Consideration about official Pariparoba Pothomorphe umbellata (L.). Miq Rev Bras Farmacog 1986; 1: 101-108.

3. Silva RAD. Pharmacopeia dos Estados Unidos do Brasil. 1st edn. São Paulo: Companhia Editora Nacional; 1926.

4. Ropke CD, Sawada TC, da Silva V, Michalany NS, de Moraes Barros SB. Photoprotective effect of Pothomorphe umbellata root extract against ultraviolet radiation induced chronic skin damage in the hairless mouse. Clin Exp Dermatol 2005; 30: 272-276.

5. Perazzo FF, Souza GH, Lopes W, Cardoso LG, Carvalho ties through steroidal receptors and membrane alteration that induce apoptotic processes among other effects (17).

The present study is the first that shows $P$. umbellata DCE cytotoxic activity, with high potency for cell growth inhibition at low concentrations (below $10 \mu \mathrm{g} / \mathrm{mL}$ ), and also with in vivo activity in EAT model. In this model, $P$. umbellata DCE antitumor action was confirmed by prolongation of the life span. These results are very important, considering that the control group died 25 days after tumor cell inoculation compared to 55 days for the first death in the group treated with $300 \mathrm{mg} / \mathrm{kg}$. The 100 and $200 \mathrm{mg} / \mathrm{kg}$ doses also presented a similar effect. The 100, 200 and $300 \mathrm{mg} / \mathrm{kg}$ doses can act as a therapeutic compound with no serious adverse reactions. Whereas with the $400 \mathrm{mg} / \mathrm{kg}$ dose, quick death indicates that this dose is closer to the lethal dose than to the therapeutic one. In previous studies, the activity of diverse $P$. umbellata extracts in in vitro and in vivo models demonstrated that this species can be a potential source of new therapeutic agents for the treatment of inflammatory disease (4-6). This anti-inflammatory activity could partially explain the in vivo antitumor activity observed with DCE since the literature has shown a good relationship between these activities (18). DCE also presented anti-inflammatory activity when evaluated on ear edema induced by croton oil (Sacoman JL, Foglio MA, Carvalho JE, unpublished data).

In conclusion, the anticancer activity of the extract and fractions from $P$. umbellata observed in these experimental models suggests the participation of different compounds with distinct mechanisms of action. These results are very consistent with others demonstrating the huge potential of the Piperaceae family as a source for new drug development (19).
JC, Nanayakkara NP, et al. Anti-inflammatory and analgesic properties of water-ethanolic extract from Pothomorphe umbellata (Piperaceae) aerial parts. J Ethnopharmacol 2005; 99: 215-220.

6. Nunez V, Castro V, Murillo R, Ponce-Soto LA, Merfort I, Lomonte B. Inhibitory effects of Piper umbellatum and Piper peltatum extracts towards myotoxic phospholipases A2 from Bothrops snake venoms: isolation of 4-nerolidylcatechol as active principle. Phytochemistry 2005; 66: 1017-1025.

7. Kijjoa A, Giesbrecht AM, Akisue MK, Gottlieb OR, Gottlieb HE. 4-Nerolidylcatechol from Pothomorphe umbellata. Planta Med 1980; 39: 85-87.

8. Mongelli E, Romano A, Desmarchelier C, Coussio J, Ciccia 
G. Cytotoxic 4-nerolidylcatechol from Pothomorphe peltata inhibits topoisomerase I activity. Planta Med 1999; 65: 376378.

9. Pinto ACS, Pessoa C, Lotufo LVC, Moraes MOM, Moraes $\mathrm{ME}$, Cavalcanti BC, et al. In vitro cytotoxicity of Pothomorphe peltata (L.) Miquel (Piperaceae) isolated 4-nerolidylcatechol and its semi-synthetic diacetyl derivative. Rev Bras PI Med 2006; 8: 205-211.

10. Skehan P, Storeng R, Scudiero D, Monks A, McMahon J, Vistica D, et al. New colorimetric cytotoxicity assay for anticancer-drug screening. J Natl Cancer Inst 1990; 82: 11071112.

11. Holbeck SL. Update on $\mathrm{NCl}$ in vitro drug screen utilities. Eur J Cancer 2004; 40: 785-793.

12. Litchfield JT Jr, Wilcoxon F. The reliability of graphic estimates of relative potency from dose-per cent effect curves. J Pharmacol Exp Ther 1953; 108: 18-25.

13. Vincent PC, Nicholls A. Comparison of the growth of the Ehrlich ascites tumor in male and female mice. Cancer Res 1967; 27: 1058-1065.
14. Ullman-Cullere MH, Foltz CJ. Body condition scoring: a rapid and accurate method for assessing health status in mice. Lab Anim Sci 1999; 49: 319-323.

15. Adams RP. Identification of essential oil components by gas chromatography/mass spectroscopy. Carol Stream: Allured Publishing Corporation; 1995.

16. Gustafson KR, Cardellina II JH, McMahon JB, Pannell LK, Cragg GM, Boyd MR. The peltatols, novel HIV-inhibitory catechol derivatives from Pothomorphe umbellata. J Org Chem 1992; 57: 2809-2811.

17. Awad AB, Fink CS. Phytosterols as anticancer dietary components: evidence and mechanism of action. J Nutr 2000; 130: 2127-2130.

18. Meric JB, Rottey S, Olaussen K, Soria JC, Khayat D, Rixe $\mathrm{O}$, et al. Cyclooxygenase-2 as a target for anticancer drug development. Crit Rev Oncol Hematol 2006; 59: 51-64.

19. Parmar VS, Jain SC, Bisht KS, Jain R, Taneja P, Jha A, et al. Phytochemistry of genus Piper. Phytochemistry 1997; 46: 597-673. 